\title{
Application of Film Hole Irrigation on Borders for Water Saving and Sunflower Production
}

\author{
Muhammad Saeed · Sajid Mahmood
}

Received: 31 March 2011 / Accepted: 11 July 2011 / Published online: 14 March 2013

(C) The Author(s) 2013. This article is published with open access at Springerlink.com

\begin{abstract}
Film hole irrigation is relatively reported efficient irrigation technique amongst the others by Chinese's researchers. Film hole irrigation refers to bordered field completely covered with plastic sheet having holes of equal sizes through which seedlings come out. Field experiments were conducted at Postgraduate Agriculture Research Station to check its effectiveness and performance in terms of advance rate on sunflower crop for various sized borders having Fine Sandy Loam soil. Tube well irrigation water was applied with an average discharge of $21 \mathrm{l} / \mathrm{s}$ and field data were collected from each plot during 1st, 2nd and 3rd irrigations. Results of the study revealed that advance time taken during film hole method in completing the advance phase was comparatively less as compared with the conventional irrigation. Water saving of 37-45\% was observed by film hole irrigation, and the yield of sunflower crop was $23-30 \%$ higher as compared with conventional irrigation. The field management issues were also discussed and addressed properly.
\end{abstract}

Keywords Film hole irrigation - Sunflower .

Water saving - Advance time

M. Saeed ( $\varangle) \cdot$ S. Mahmood

Centre of Excellence in Water Resources Engineering, University of Engineering and Technology, Lahore, Pakistan e-mail: engrsaeed_47@yahoo.com



\section{Introduction}

Application of water to the field wisely and efficiently for maximizing crop production is the main goal in irrigated agriculture. Pakistan is an agricultural country and mostly the water applied for agricultural production is by surface irrigation but still yields per unit of water in Pakistan is lowest in contrast to other countries [1]. Water is becoming one of the major constraints for agricultural and economic development in the country. Continuous increasing country's population requires parallel increase in agriculture to meet the food and fiber production in the country. To overcome such alarming situations, the irrigators recently have diverted their attention towards pressurized irrigation systems. But it is too costly and need skilled labour that lacks in the country. Another option to tackles present situation is the adoptability of new innovative water management irrigation techniques [2]. Today, the need for saving irrigation water can be judged from the figure that the crops utilize $34 \%$ of water entering the canals and 
the rest get lost some way or the other. This is a colossal loss and it is our paramount duty to save this loss and increase the agricultural production. The Government can check only the loss that occurs in canals, branches and minors but the loss that occurs in the watercourses and agricultural fields be checked by the farmers only [3]. Therefore, every effort should be made to introduce such irrigation methods that farmers can adopt to minimize the loss of water by improving system performance and maximize their benefits from the limited water resources. One way to improve this situation is the application of film hole irrigation [4].

Film hole irrigation is relatively a new irrigation method that refers to the bordered field completely covered with plastic film having holes of equal sizes [5]. Water penetrates into soil through holes during irrigation and seedlings come out from these holes. The benefits associated with film hole irrigation are directly related to the tremendous reduction in losses due to field infiltration and evaporation.Its advantages over other surface irrigation methods are faster water advance, water saving and increased in crop yields.

Present study was an attempt to evaluate the impact of film hole irrigation in terms of water advances on borders and in estimating the benefits associated with it in terms of water saving and crop yields compared with conventional irrigation. The field management issues would be of more importance for researchers and farmers and highlighted properly under local environment.

\section{Material and Methods}

Field experiments were conducted on different sized borders CT1 $(48 \times 5 \mathrm{~m})$, CT2 $(48 \times 3 \mathrm{~m})$, CT3 $(24 \times 5 \mathrm{~m})$, CT4
$(24 \times 3 \mathrm{~m})$, FT1 $(48 \times 5 \mathrm{~m})$, FT2 $(48 \times 3 \mathrm{~m})$, FT3 $(24 \times$ $5 \mathrm{~m}), \mathrm{FT} 4(24 \times 3 \mathrm{~m})$, whereas CT shows control/conventional treatment and FT shows as film hole treatment for sunflower crop production. Three sites were selected at Postgraduate Agricultural Research Centre, of the University of Agriculture Faisalabad and each site consisted of eight plots conventional and film hole water application on different sized borders (Fig. 1). Borders layout was the same for the others sites, which was random rather than systematic. The borders were manually prepared having a gentle slope of $0.2 \%$. The soil of the experimental sites was found as Fine sandy loam with an average composition of $50 \%$ of sand, $20 \%$ of silt and $30 \%$ of clay. Plastic sheets were spread on the borders in accordance with the size of the borders and holes were prepared on sheet with the help of $5 \mathrm{~cm}$ diameter sharpen edge pipe. The plant to plant distance was set as $22 \mathrm{~cm}$ and row to row distance was kept as $60 \mathrm{~cm}$ (Fig. 2). Then film hole plots and open field plots were sown with hybrid sunflower seeds. The moisture level in the soil was measured with the help of speedy moisture meter during experimentation and irrigation water was applied at $12-15 \%$ of soil moisture level in the field. Water was applied with the help of cut throat flume, permanently installed in the field watercourse having an average discharge of $21 \mathrm{l} / \mathrm{s}(0.75 \mathrm{cfs})$ during irrigations. Irrigation was applied after one month of sowing of the crop and the advance of flowing water was measured in each plot by placing stakes at $10-\mathrm{m}$ intervals starting from the inlet end of the border with the help of stopwatch. Performance indicators like volume ratio (VR), advance-time ratio (ATR), and water use efficiency (WUE) were used to assess and compared the effectiveness of film hole irrigation with the conventional irrigation on borders. Average of the field data collected was used here in this article to present the results.

(Treatment through Random Selection)

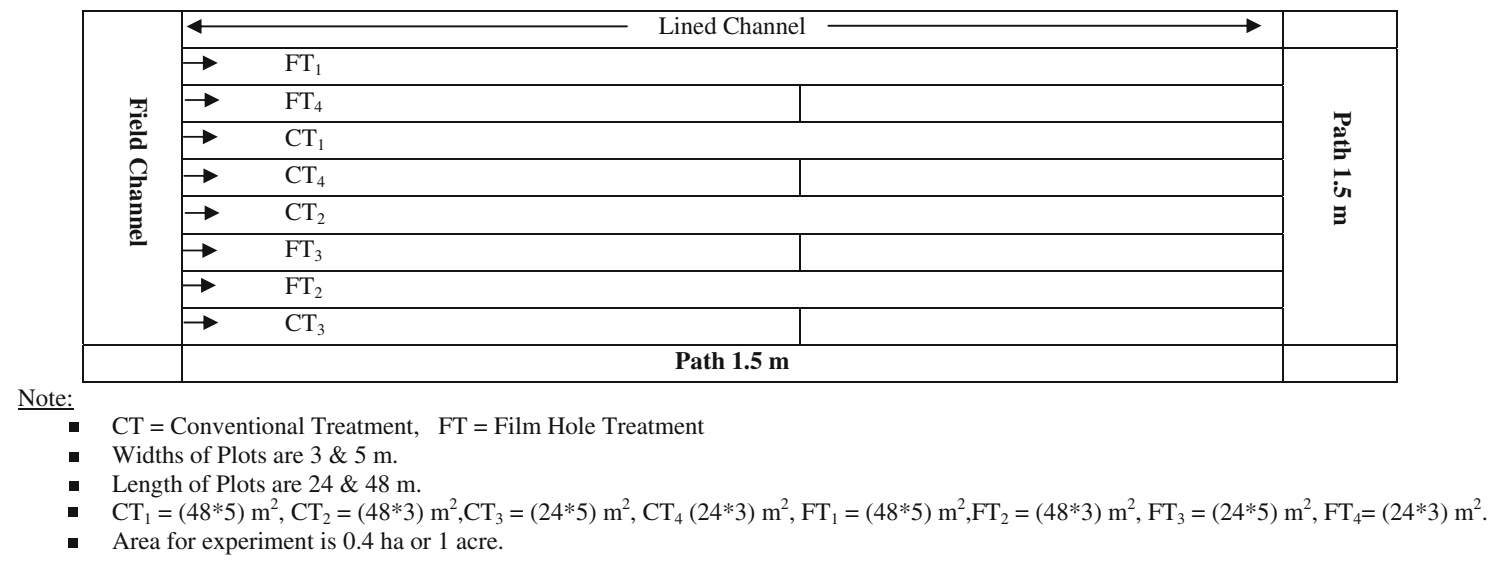

Fig. 1 Field layout and experimental setup 


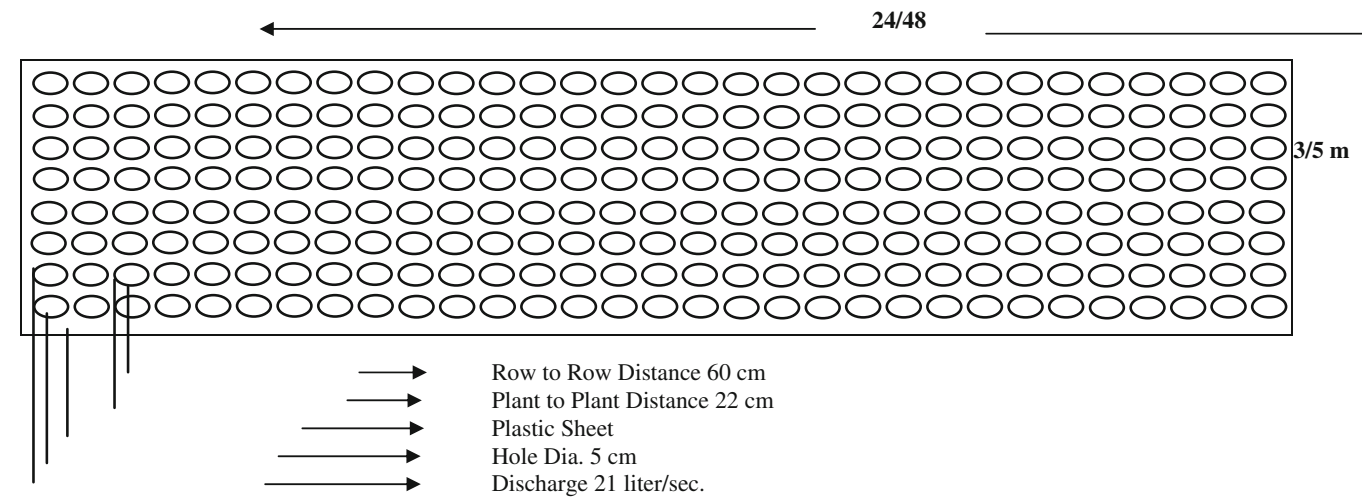

Fig. 2 Film holes pattern in the plastic sheet

\section{Performance Indicators}

\subsection{Advance Rate Performance Indicators}

Conceptually, the performance of an irrigation system for an individual application is dependent on the water stored and utilized only for beneficial crop growth. The present study focuses on the advance rate and crop growth in film hole irrigation and conventional irrigation techniques; the efficiencies terms are not considered here and performance indicators like volume ratio and advance-time ratio were used to compare the hydraulic performance of irrigation systems[2]. These indicators/functions are described as:

Volume ratio One measure of the effectiveness of FH irrigation in hastening advance expressed as the volume ratio given as

$\mathrm{VR}=\frac{V_{\mathrm{wfh}}}{V_{\mathrm{wc}}}$

where VR is the volume ratio; $V_{\mathrm{wfh}}$ is the total volume of water used to advance the wetting front to the end of the field during film hole irrigation and $V_{\mathrm{wc}}$ is the volume required for waterfront advance during conventional irrigation in $\mathrm{m}^{3}$.

Advance-time ratio Faster advance during film hole irrigation reduces travel time of the water front advance to the end of the field compared with conventional water application. To determine the advance-time reduction for film hole irrigation compared with its counter part, the advance time was normalized relative to the distance covered by the advancing waterfront in film hole irrigated borders and during conventional irrigations and is expressed as 'Advance time ratio (ATR)'

$\mathrm{ATR}=\frac{\frac{t_{\text {tha }}}{L_{\mathrm{fh}}}}{\frac{t_{\mathrm{ca}}}{L_{\mathrm{c}}}}$

where $t_{\mathrm{fha}} / L_{\mathrm{fh}}$ is the normalized advance time during film hole irrigation and $t_{\mathrm{ca}} / L_{\mathrm{c}}$ is the normalized advance time for conventional irrigation.

\subsection{Crop Performance Indicators}

Following two crop performance indicators are described as under:

(a) Seed germination and mortality rate Sun Flower crop was grown for the experiment of film hole irrigation contrast to conventional irrigation method. It was observed from the experiment that seed germination rate was $90-95 \%$ and mortality rate was $5-10 \%$ in the film hole irrigated plots. On the other hand, the seed germination rate was observed as $80-85 \%$ and mortality rate was noted as $15-$ $20 \%$ in case of conventional irrigation plots. This difference was due to continuously soil moisture available in the film hole irrigated plots contrast to conventional irrigated plots, where the moisture was reduced due to open soil surface.

(b) Crop growth/crop height and girth The second crop performance indicator was observed as crop growth/crop height and girth of sunflower crop with film hole irrigated plots contrast to conventional irrigated plots. It was noted that height and girth of the sunflower plants were double in case of film hole irrigated plots contrast to conventional irrigated plots. The height and girth of the plants were double due to the moisture conservation with the help of film hole irrigation technology.

\section{Results and Discussion}

\subsection{Time Saving}

Table 1 presents the average advance rate data for both film hole and conventional irrigated plots of sizes $(48 \times 5) \mathrm{m}^{2}$ and $(48 \times 3) \mathrm{m}^{2}$ during $1 \mathrm{st}$, 2nd and 3rd irrigations in growing of sunflower crop. It can be seen from the table that a reduction in the advance time of $10-11 \%$ occurred in completing the advance phase during film hole irrigation in various sized 
Table 1 Average advance time during different irrigations

\begin{tabular}{|c|c|c|c|c|c|}
\hline \multirow[t]{3}{*}{ Irrigation } & \multirow[t]{3}{*}{ Distance from inlet (m) } & \multicolumn{4}{|l|}{ Advance time (min) } \\
\hline & & \multicolumn{2}{|l|}{ Border size $(48 \times 5 \mathrm{~m})$} & \multicolumn{2}{|l|}{ Border size $(48 \times 3 \mathrm{~m})$} \\
\hline & & Film hole & Conventional & Film hole & Conventional \\
\hline \multirow[t]{5}{*}{ First irrigation } & 10 & 4.15 & 5.33 & 0.93 & 1.29 \\
\hline & 20 & 8.85 & 10.45 & 1.95 & 2.47 \\
\hline & 30 & 12.61 & 13.27 & 3.3 & 4.13 \\
\hline & 40 & 15.56 & 16.65 & 4.82 & 5.78 \\
\hline & 48 & 18.13 & 20.15 & 7.53 & 8.45 \\
\hline \multirow[t]{5}{*}{ Second irrigation } & 10 & Irrigation was not applied & 1.54 & Irrigation was not applied & 1.23 \\
\hline & 20 & & 3.5 & & 2.8 \\
\hline & 30 & & 5.75 & & 4.64 \\
\hline & 40 & & 7.76 & & 6.81 \\
\hline & 48 & & 11.73 & & 8.79 \\
\hline \multirow[t]{5}{*}{ Third irrigation } & 10 & 1.07 & 1.15 & 0.79 & 0.8 \\
\hline & 20 & 1.66 & 2.36 & 1.69 & 1.75 \\
\hline & 30 & 2.34 & 3.98 & 2.75 & 2.83 \\
\hline & 40 & 4.24 & 5.76 & 4.02 & 4.23 \\
\hline & 48 & 8 & 10.25 & 5.85 & 6.89 \\
\hline
\end{tabular}

Table 2 Average advance time during different irrigations

\begin{tabular}{|c|c|c|c|c|c|}
\hline \multirow[t]{3}{*}{ Irrigation } & \multirow[t]{3}{*}{ Distance from inlet (m) } & \multicolumn{4}{|l|}{ Advance time (min) } \\
\hline & & \multicolumn{2}{|l|}{ Border size $(24 \times 5 \mathrm{~m})$} & \multicolumn{2}{|l|}{ Border size $(24 \times 3 \mathrm{~m})$} \\
\hline & & Film hole & Conventional & Film hole & Conventional \\
\hline \multirow[t]{3}{*}{ First irrigation } & 10 & 3.16 & 3.5 & 1.1 & 1.2 \\
\hline & 20 & 5.89 & 6.76 & 2.28 & 2.47 \\
\hline & 24 & 8.08 & 9.03 & 3.77 & 4.35 \\
\hline \multirow[t]{3}{*}{ Second irrigation } & 10 & Irrigation not required & 2.3 & Irrigation not required & 1.05 \\
\hline & 20 & & 4.13 & & 2.27 \\
\hline & 24 & & 5.39 & & 3.27 \\
\hline \multirow[t]{3}{*}{ Third irrigation } & 10 & 1.08 & 1.12 & 0.4 & 0.82 \\
\hline & 20 & 2.17 & 2.18 & 1.26 & 2.31 \\
\hline & 24 & 3.31 & 3.74 & 2.81 & 4.15 \\
\hline
\end{tabular}

borders (Table 1), contrast to conventional irrigation during 1st irrigation. This reduction was expected as the water moved relatively faster over the plastic sheet during film hole irrigation [5].

The second irrigation was not applied to the film hole irrigated plots because of conservation of water and the availability of moisture level to the tune of $45 \%$ in the field at the time of 2 nd irrigation. This was due to conservation of the moisture below the plastic sheet that actually related to the reduction in evaporation losses. There was no need of supplementing water to the film hole irrigated plots and this can be considered as marvelous benefit of using film hole as compared with conventional irrigation, i.e. $100 \%$ saving of water during 2nd irrigation.

With regard to that the third irrigation was applied after 78 days of 1 st irrigation, a reduction in advance time was observed as $15-22 \%$ in $\mathrm{FT}_{3}(24 \times 5)$ and $\mathrm{FT}_{4}(24 \times 3)$ plots, respectively, as compared with conventional irrigated plots (Table 2). A higher value during 3rd irrigation contrast to first irrigation may be due to compaction of soil and less infiltration losses in the irrigated plots [6]. It is obvious from the data that less time was required to complete the advance phase in film hole irrigated borders compared with conventional irrigated plots. 
Table 3 Average advance time ratio and time saving percentage during different irrigations

\begin{tabular}{|c|c|c|c|c|c|c|}
\hline Irrigation event & Technique & Treatment & Flow rate $(1 / s)$ & Irrigation time (min) & ATR & Time saving (\%) \\
\hline \multicolumn{7}{|c|}{ Border size $(48 \times 5) \mathrm{m}^{2}$} \\
\hline \multirow[t]{2}{*}{ I } & Film hole & $\mathrm{FH}_{1}$ & 21 & 18.13 & \multirow[t]{2}{*}{0.90} & \multirow[t]{2}{*}{10} \\
\hline & Conventional & $\mathrm{CT}_{1}$ & 21 & 20.15 & & \\
\hline \multirow[t]{2}{*}{ II } & Film hole & $\mathrm{FH}_{1}$ & \multicolumn{2}{|c|}{ Irrigation was not required } & & \multirow[t]{2}{*}{100} \\
\hline & Conventional & $\mathrm{CT}_{1}$ & 21 & 11.73 & & \\
\hline \multirow[t]{2}{*}{ III } & Film hole & $\mathrm{FH}_{1}$ & 21 & 8 & 0.78 & \multirow[t]{2}{*}{22} \\
\hline & Conventional & $\mathrm{CT}_{1}$ & 21 & 10.25 & & \\
\hline \multicolumn{7}{|c|}{ Border size $(48 \times 3) \mathrm{m}^{2}$} \\
\hline \multirow[t]{2}{*}{ I } & Film hole & $\mathrm{FH}_{2}$ & 21 & 7.53 & \multirow[t]{2}{*}{0.89} & \multirow[t]{2}{*}{11} \\
\hline & Conventional & $\mathrm{CT}_{2}$ & 21 & 8.45 & & \\
\hline \multirow[t]{2}{*}{ II } & Film hole & $\mathrm{FH}_{2}$ & \multicolumn{2}{|c|}{ Irrigation was not required } & & \multirow[t]{2}{*}{100} \\
\hline & Conventional & $\mathrm{CT}_{2}$ & 21 & 8.79 & & \\
\hline \multirow[t]{2}{*}{ III } & Film hole & $\mathrm{FH}_{2}$ & 21 & 5.85 & 0.85 & \multirow[t]{2}{*}{15} \\
\hline & Conventional & $\mathrm{CT}_{2}$ & 21 & 6.89 & & \\
\hline \multicolumn{7}{|c|}{ Border size $(24 \times 5) \mathrm{m}^{2}$} \\
\hline \multirow[t]{2}{*}{ I } & Film hole & $\mathrm{FH}_{3}$ & 21 & 8.08 & \multirow[t]{2}{*}{0.89} & \multirow[t]{2}{*}{11} \\
\hline & Conventional & $\mathrm{CT}_{3}$ & 21 & 9.03 & & \\
\hline \multirow[t]{2}{*}{ II } & Film hole & $\mathrm{FH}_{3}$ & \multicolumn{2}{|c|}{ Irrigation was not required } & & \multirow[t]{2}{*}{100} \\
\hline & Conventional & $\mathrm{CT}_{3}$ & 21 & 6.42 & & \\
\hline \multirow[t]{2}{*}{ III } & Film hole & $\mathrm{FH}_{3}$ & 21 & 3.31 & 0.94 & \multirow[t]{2}{*}{6} \\
\hline & Conventional & $\mathrm{CT}_{3}$ & 21 & 3.52 & & \\
\hline \multicolumn{7}{|c|}{ Border size $(24 \times 3) \mathrm{m}^{2}$} \\
\hline \multirow[t]{2}{*}{ I } & Film hole & $\mathrm{FH}_{4}$ & 21 & 3.77 & \multirow[t]{2}{*}{0.87} & \multirow[t]{2}{*}{13} \\
\hline & Conventional & $\mathrm{CT}_{4}$ & 21 & 4.35 & & \\
\hline II & Film hole & $\mathrm{FH}_{4}$ & Irrigation was & uired & & 100 \\
\hline & Conventional & $\mathrm{CT}_{4}$ & 21 & 3.27 & & \\
\hline III & Film hole & $\mathrm{FH}_{4}$ & 21 & 2.81 & 0.68 & 32 \\
\hline & Conventional & $\mathrm{CT}_{4}$ & 21 & 4.15 & & \\
\hline
\end{tabular}

\subsection{Average Advance Time Ratio}

Table 3 presents the average advance time ratio (ATR) and time saving percentages during different irrigations. It was observed from the data that average time ratio as calculated by Eq. (2), found to be 0.90 and 0.78 and 0.89 and 0.85 during 1 st and 3rd irrigation, respectively, for film hole irrigated plots having sizes of $(48 \times 5) \mathrm{m}^{2}$ and $(48 \times 3) \mathrm{m}^{2}$ compared with conventional irrigated plots of same sizes. Second irrigation was not applied to film hole irrigated plots due to sufficient moisture available in the experimental field. In the same way, advance time ratio was also calculated as 0.89 and 0.94 , and 0.87 and 0.68 , respectively, for the film hole plots of sizes $\mathrm{FT}_{3}(24 \times 5) \mathrm{m}^{2}$ and $\mathrm{FT}_{4}(24 \times 3) \mathrm{m}^{2}$ (Table 3$)$.

The graphical representations of advance flow time from head to tail of the experimental plot are presented in Figs. 3, 4, 5 and 6 for first and third irrigations. In these figures, it is clear that the less time was taken with film hole irrigation as compared with conventional irrigation method. In all these cases, the film hole irrigation method proved to be the efficient irrigation method as compared with conventional irrigation method. In Fig. 3 the treatment $\mathrm{FT}_{1}$ was compared with $\mathrm{CT}_{1}$ and $\mathrm{FT}_{2}$ with $\mathrm{CT}_{2}$. In both sets, time was decreased by $10-11 \%$ (Table 1 ), the film hole irrigation plots of $48 \mathrm{~m}$ length with 5 and $3 \mathrm{~m}$ widths. The time reduction was occurred in both cases of film hole irrigation plots as compared with conventional irrigation plots of same sizes at the time of first irrigation (Fig. 3). The maximum reduction in time was observed in $(48 \times 3) \mathrm{m}^{2}$ size plot. This figure shows a big gap between time taken with these two types of plot sizes, i.e. $(48 \times 5) \mathrm{m}^{2}$ and $(48 \times 3) \mathrm{m}^{2}$; the narrow width plots took less time than the wider plot and it was also expected that more time was required for wider plot of size $(48 \times 5) \mathrm{m}^{2}$ than the narrow width plot of size $(48 \times 3) \mathrm{m}^{2}$. More time was also taken by the wider plots due to their greater width and less soil moisture available in these plots. 


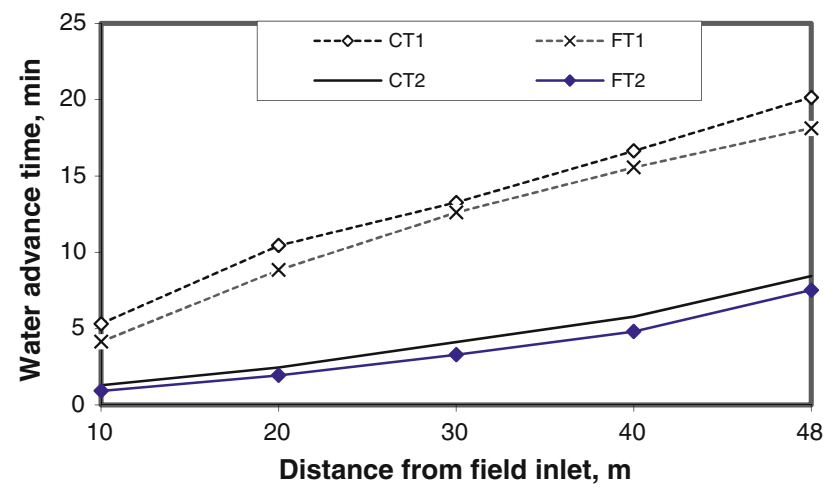

Fig. 3 Average advance rate compared with $\mathrm{FT}_{1}, \mathrm{CT}_{1}, \mathrm{FT}_{2}$ and $\mathrm{CT}_{2}$ during first irrigation

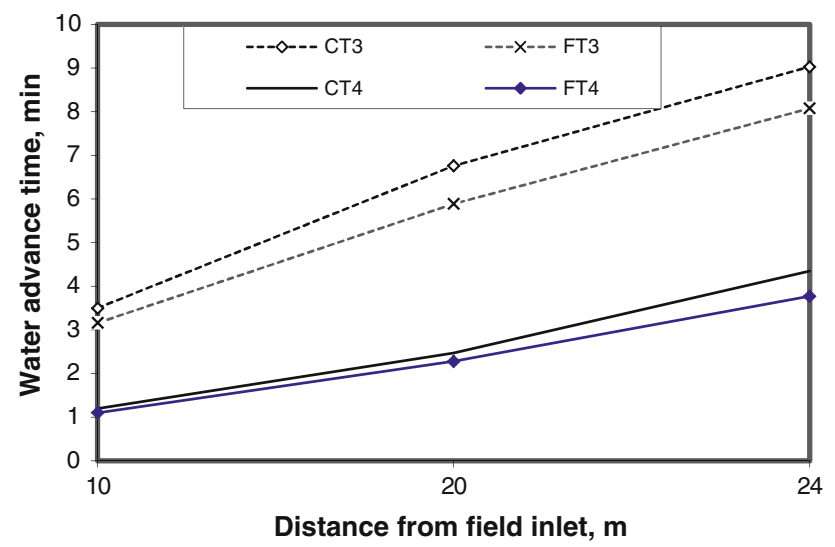

Fig. 4 Average advance rate compared with $\mathrm{FT}_{3}$ and $\mathrm{CT}_{3}$ and $\mathrm{FT}_{4}$ and $\mathrm{CT}_{4}$ during first irrigation

In Fig. 4, the treatment of $\mathrm{FT}_{3}$ was compared with $\mathrm{CT}_{3}$, and $\mathrm{FT}_{4}$ was compared with $\mathrm{CT}_{4}$. In both sets, time was decreased by $11-13 \%$ (Table 2), with film hole irrigation plots of $24 \mathrm{~m}$ length and 5 and $3 \mathrm{~m}$ widths as compared with conventional irrigated plots. The time reduction was more in $3 \mathrm{~m}$ width as compared with $5 \mathrm{~m}$ width of plot due to narrow width at the time of first irrigation.

In Fig. 5, the treatment of $\mathrm{FT}_{1}$ was compared with $\mathrm{CT}_{1}$ and $\mathrm{FT}_{2}$ with $\mathrm{CT}_{2}$ during third irrigation. In both sets of plots, time was decreased from 22 to $15 \%$ (Table 1), of film hole irrigation with $48 \mathrm{~m}$ length and 3 and $5 \mathrm{~m}$ widths. The time reduction was more in $5 \mathrm{~m}$ width of film hole irrigated plot as compared with $3 \mathrm{~m}$ width of plot with film hole irrigated plot at the time of third irrigation due to unknown reasons. It might be due to more moisture available in the $5 \mathrm{~m}$ width plot than $3 \mathrm{~m}$ width plot.

In Fig. 6, the treatment $\mathrm{FT}_{3}$ was compared with $\mathrm{CT}_{3}$ and $\mathrm{FT}_{4}$ with $\mathrm{CT}_{4}$. In both sets of plots, time was decreased by $11-32 \%$ (Table 2), with film hole irrigated plots of $24 \mathrm{~m}$ length and 3 and $5 \mathrm{~m}$ widths. The time reduction was more in $3 \mathrm{~m}$ width of plot as compared with 5 meter width of film

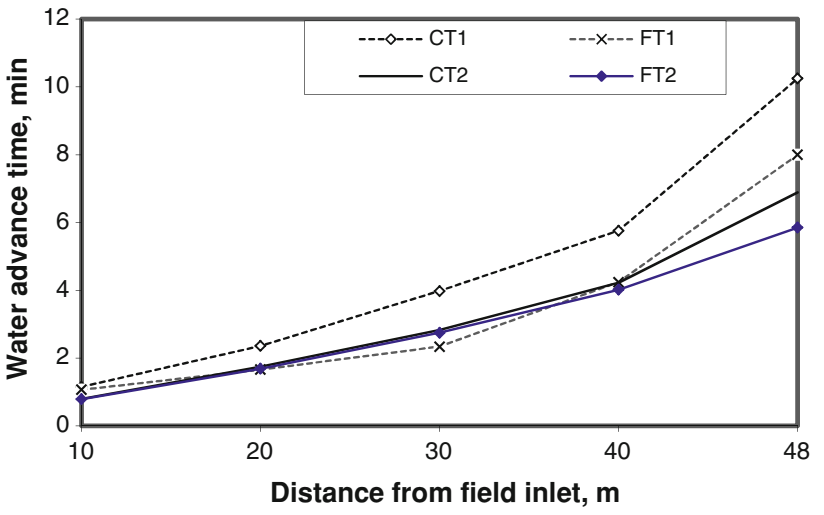

Fig. 5 Average advance rate compared with $\mathrm{FT}_{1}, \mathrm{CT}_{1}, \mathrm{FT}_{2}$ and $\mathrm{CT}_{2}$ during third irrigation

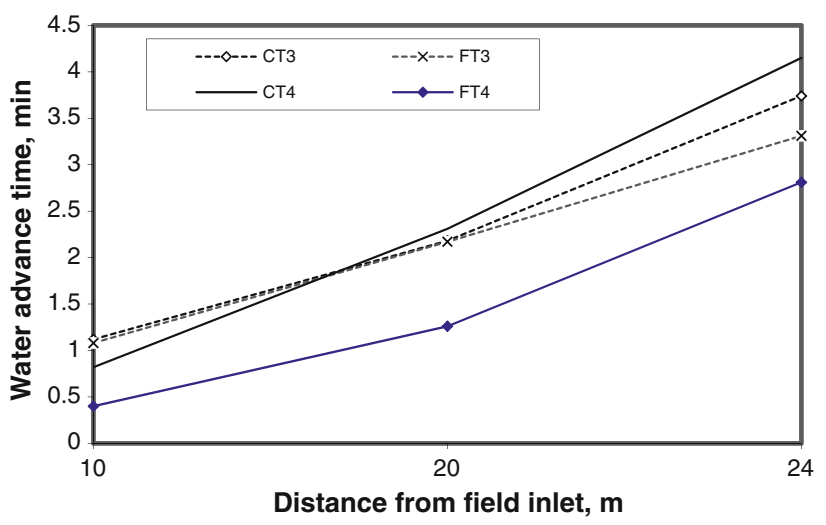

Fig. 6 Average advance rate compared with $\mathrm{FT}_{3}, \mathrm{CT}_{3}, \mathrm{FT}_{4}$ and $\mathrm{CT}_{4}$ during third irrigation

hole irrigated plot at the time of third irrigation as it was also expected.

\subsection{Water Saving}

Water saving can be expressed in terms of volume ratio, which can be defined as the ratio of volume of water applied during film hole irrigation to the volume of water applied to the conventional irrigation method [7]. Water saving is calculated in Table 4 with different plot sizes of film hole irrigation. The water saving with plot size $(48 \times 5) \mathrm{m}^{2}$ of film hole irrigation was $10 \%$ in first irrigation, $100 \%$ water saving with second irrigation and $22 \%$ with third irrigation as compared with conventional irrigation plots of same sizes. The water was saved with film hole irrigated plot of size $(48 \times 3) \mathrm{m}^{2}$ as $11 \%$ in first irrigation, $100 \%$ in second irrigation and $15 \%$ in third irrigation as compared with conventional irrigation plots of same sizes. In the same way, irrigation water was saved with film hole irrigated plot sizes of $(24 \times 5) \mathrm{m}^{2}$ as $11 \%$ in first irrigation, $100 \%$ in second irrigation and $6 \%$ with third irrigation as compared with conventional irrigated plots. Water was also saved as $13 \%$ 
Table 4 Average volume of water used by sunflower crop during different irrigations

\begin{tabular}{|c|c|c|c|c|c|c|c|}
\hline Irrigation event & Technique & Treatment & $\begin{array}{l}\text { Flow rate } \\
(1 / \mathrm{s})\end{array}$ & $\begin{array}{l}\text { Irrigation time } \\
(\mathrm{min})\end{array}$ & $\begin{array}{l}\text { Volume applied } \\
\text { (cumecs) }\end{array}$ & Volume ratio & $\begin{array}{l}\text { Water saving } \\
(\%)\end{array}$ \\
\hline \multicolumn{8}{|c|}{ Border size $(48 \times 5) \mathrm{m}^{2}$} \\
\hline \multirow[t]{2}{*}{ I } & Film hole & $\mathrm{FH}_{1}$ & 21 & 18.13 & 22.84 & 0.90 & 10 \\
\hline & Conventional & $\mathrm{CT}_{1}$ & 21 & 20.15 & 25.39 & & \\
\hline \multirow[t]{2}{*}{ II } & Film hole & $\mathrm{FH}_{1}$ & \multicolumn{4}{|c|}{ Irrigation was not required } & 100 \\
\hline & Conventional & $\mathrm{CT}_{1}$ & 21 & 11.73 & 14.77 & & \\
\hline \multirow[t]{2}{*}{ III } & Film hole & $\mathrm{FH}_{1}$ & 21 & 8 & 10.08 & 0.78 & 22 \\
\hline & Conventional & $\mathrm{CT}_{1}$ & 21 & 10.25 & 12.91 & & \\
\hline \multicolumn{8}{|c|}{ Border size $(48 \times 3) \mathrm{m}^{2}$} \\
\hline \multirow[t]{2}{*}{ I } & Film hole & $\mathrm{FH}_{2}$ & 21 & 7.53 & 9.48 & 0.89 & 11 \\
\hline & Conventional & $\mathrm{CT}_{2}$ & 21 & 8.45 & 10.65 & & \\
\hline \multirow[t]{2}{*}{ II } & Film hole & $\mathrm{FH}_{2}$ & \multicolumn{4}{|c|}{ Irrigation was not required } & 100 \\
\hline & Conventional & $\mathrm{CT}_{2}$ & 21 & 8.79 & 11.07 & & \\
\hline \multirow[t]{2}{*}{ III } & Film hole & $\mathrm{FH}_{2}$ & 21 & 5.85 & 7.36 & 0.85 & 15 \\
\hline & Conventional & $\mathrm{CT}_{2}$ & 21 & 6.89 & 8.68 & & \\
\hline \multicolumn{8}{|c|}{ Border size $(24 \times 5) \mathrm{m}^{2}$} \\
\hline \multirow[t]{2}{*}{ I } & Film hole & $\mathrm{FH}_{3}$ & 21 & 8.08 & 10.17 & 0.89 & 11 \\
\hline & Conventional & $\mathrm{CT}_{3}$ & 21 & 9.03 & 11.37 & & \\
\hline \multirow[t]{2}{*}{ II } & Film hole & $\mathrm{FH}_{3}$ & \multicolumn{4}{|c|}{ Irrigation was not required } & 100 \\
\hline & Conventional & $\mathrm{CT}_{3}$ & 21 & 6.42 & 8.08 & & \\
\hline \multirow[t]{2}{*}{ III } & Film hole & $\mathrm{FH}_{3}$ & 21 & 3.31 & 4.17 & 0.94 & 6 \\
\hline & Conventional & $\mathrm{CT}_{3}$ & 21 & 3.52 & 4.43 & & \\
\hline \multicolumn{8}{|c|}{ Border size $(24 \times 3) \mathrm{m}^{2}$} \\
\hline \multirow[t]{2}{*}{ I } & Film hole & $\mathrm{FH}_{4}$ & 21 & 3.77 & 4.74 & 0.86 & 14 \\
\hline & Conventional & $\mathrm{CT}_{4}$ & 21 & 4.35 & 5.48 & & \\
\hline \multirow[t]{2}{*}{ II } & Film hole & $\mathrm{FH}_{4}$ & \multicolumn{3}{|c|}{ Irrigation was not required } & & 100 \\
\hline & Conventional & $\mathrm{CT}_{4}$ & 21 & 3.27 & 4.11 & & \\
\hline \multirow[t]{2}{*}{ III } & Film hole & $\mathrm{FH}_{4}$ & 21 & 2.81 & 3.54 & 0.68 & 32 \\
\hline & Conventional & $\mathrm{CT}_{4}$ & 21 & 4.15 & 5.22 & & \\
\hline
\end{tabular}

Table 5 Average volume of water used by sunflower crop during the crop season

\begin{tabular}{|c|c|c|c|c|c|c|c|}
\hline Irrigation event & Technique & Treatment & $\begin{array}{l}\text { Flow rate } \\
(1 / \mathrm{s})\end{array}$ & $\begin{array}{l}\text { Irrigation time } \\
(\mathrm{min})\end{array}$ & $\begin{array}{l}\text { Volume applied } \\
\text { (cumecs) }\end{array}$ & Volume ratio & $\begin{array}{l}\text { Water saving } \\
(\%)\end{array}$ \\
\hline \multirow[t]{8}{*}{ Seasonal } & Film hole & $\mathrm{FH}_{1}$ & 21 & 26.13 & 32.92 & 0.62 & 38 \\
\hline & Conventional & $\mathrm{CT}_{1}$ & 21 & 42.12 & 53.07 & & \\
\hline & Film hole & $\mathrm{FH}_{2}$ & 21 & 13.37 & 16.85 & 0.55 & 45 \\
\hline & Conventional & $\mathrm{CT}_{2}$ & 21 & 24.12 & 30.39 & & \\
\hline & Film hole & $\mathrm{FH}_{3}$ & 21 & 11.39 & 14.35 & 0.60 & 40 \\
\hline & Conventional & $\mathrm{CT}_{3}$ & 21 & 18.96 & 23.88 & & \\
\hline & Film hole & $\mathrm{FH}_{4}$ & 21 & 6.58 & 8.28 & 0.56 & 44 \\
\hline & Conventional & $\mathrm{CT}_{4}$ & 21 & 11.76 & 14.82 & & \\
\hline
\end{tabular}

with first irrigation, $100 \%$ with second irrigation and $32 \%$ in third irrigation with plot sizes of $(24 \times 3) \mathrm{m}^{2}$ of film hole irrigated plots as compared with conventional irrigated plots [8].
Seasonal water saving is shown in Table 5 and Fig. 7 which represent the volume of water used with different treatments up to the harvesting of the crop. Water was saved as 38 and $45 \%$ during crop season with plots size of $(48 \times 5)$ and 
Fig. 7 Average volume of water applied to sunflower crop during different irrigations

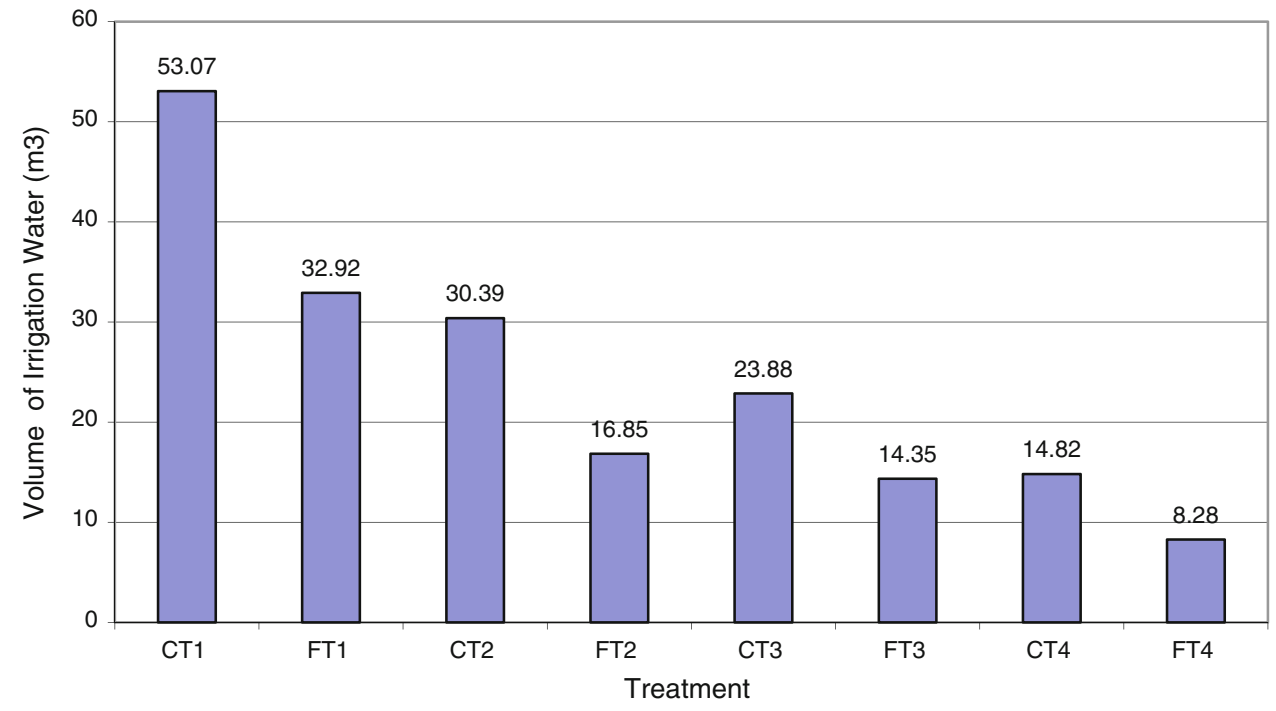

Fig. 8 A view of germination of sunflower seedlings from the film holes plots

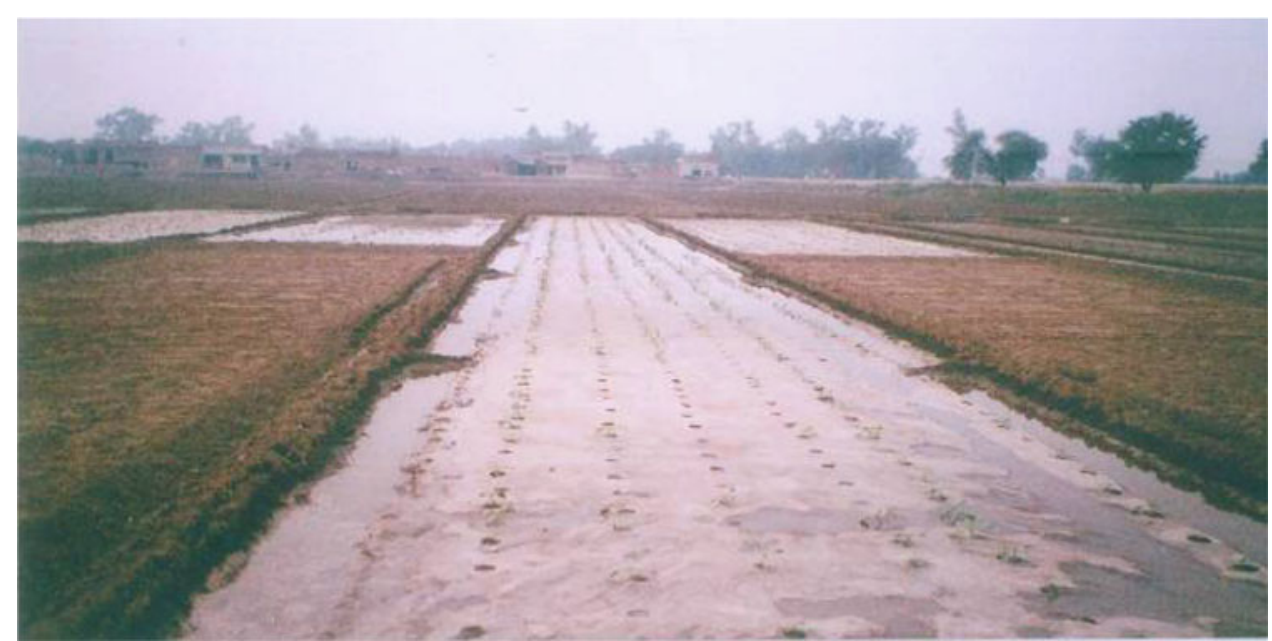

$(48 \times 3) \mathrm{m}^{2}$ of film hole irrigated plots as compared with conventional irrigated plots of same sizes. The water saving was calculated as 40 and $44 \%$ with film hole plots of sized $(24 \times$ $5) \mathrm{m}^{2}$ and $(24 \times 3) \mathrm{m}^{2}$, respectively, as compared with conventional irrigated plots of same sizes. The higher reduction in advance time was found due to the conservation of moisture, negligible evaporation due to plastic sheet which was spread on film hole irrigated plots.

\subsection{Sun Flower Germination Pattern and Crop Yield}

\subsubsection{Sun Flower Germination Pattern}

Sun flower seed germination in film hole experimental and conventional plots is shown in Figs. 8 and 9. The mortality rate was very low as $5-10 \%$ in film hole irrigated plots and it was higher as 15-20\% with conventional irrigated plots. Figures 10 and 11 show grown up plants of sunflower crop with film hole treated and conventional plots. Sun- flower plants in film hole treated plots were very healthy as compared with conventional irrigated plots; this was due to the continuous moisture available in film hole irrigated plots as compared with conventional irrigated plots. Plants in conventional irrigated plots were not so grown up due to non-availability of the moisture continuously. It was also observed that weeds germination was controlled with film hole irrigated plots as compared with conventional irrigated plots.

\subsubsection{Sunflower Crop Yield}

The yield of the crop depends upon healthy grown up of plants. It can be checked with girth and height of the plants. Therefore, the girth and height of plants were measured at the time of second irrigation, i.e. after 60 days of sowing crop from all experimental plots. Three different rows in each plot and one plant in each row were measured. It was observed from the data that the average height and girth of the plants 
Fig. 9 A view of germination of sunflower seedlings in the conventional plots

Fig. 10 A view of healthy sunflower plants grown in the film holes plots

Fig. 11 A view of sunflower plants grown in the conventional experimental plots
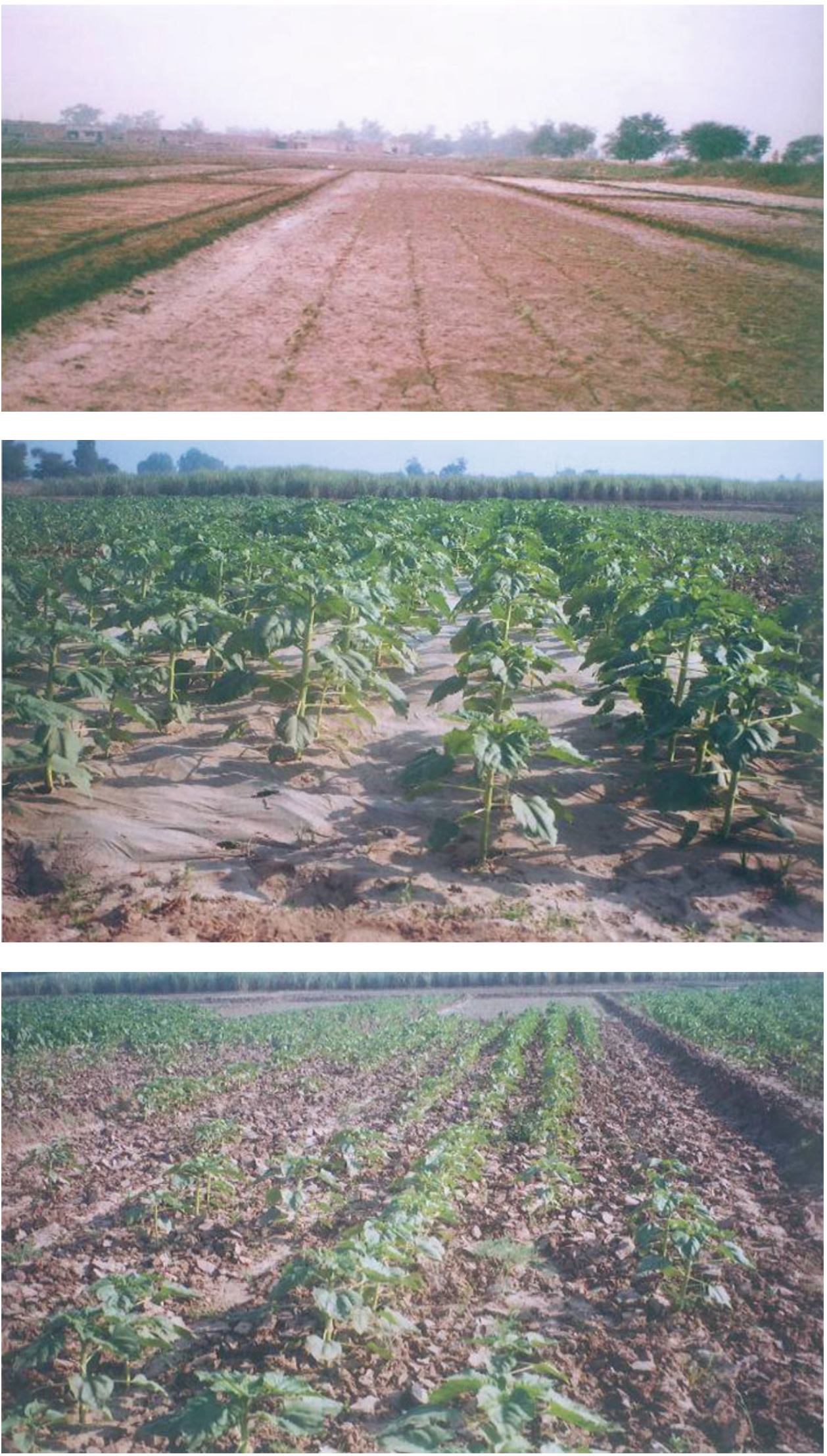

I 
Table 6 Average increase in height and girth of sunflower plants during different irrigations

\begin{tabular}{llcllr}
\hline Irrigation technique & \multicolumn{2}{l}{ After 60 days of sowing } & & \multicolumn{2}{l}{ After 110 days of sowing } \\
\cline { 2 - 3 } & Height $(\mathrm{cm})$ & Girth $(\mathrm{cm})$ & & Height $(\mathrm{cm})$ & Girth $(\mathrm{cm})$ \\
\hline Film hole & 73.21 & 7.83 & & 143.38 & 11.73 \\
Conventional & 37.71 & 4.04 & & 107.51 & 10.87 \\
Increase with film hole $(\%)$ & 94 & 94 & & 33 & 8 \\
\hline
\end{tabular}

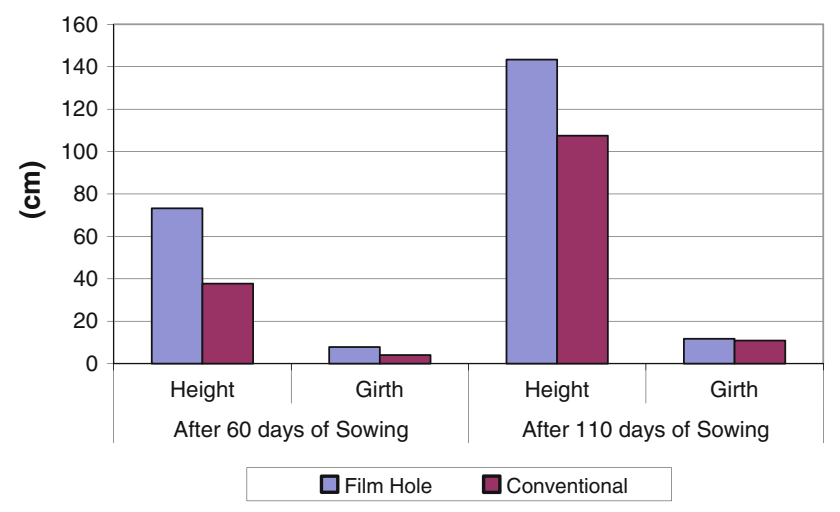

Fig. 12 Average height and girth of sunflower plants during different periods

of film hole irrigated plots were double than the conventional irrigated plants and the collected data are given in Table 6 . Second measurements were also made at the time of third irrigation, i.e. after 110 days of crop sowing. It was observed from the data that height and girth of film hole treated plants were more as 33 and $8 \%$, respectively, than the height and girth of the plants of conventional irrigated plots. The average observed data are also given in Table 6 and the graphical presentation of average height and girth of the sunflower plants are given in Fig. 12.

One of the important parameters in the evaluation of any soil-water plant system is crop yield. The sunflower crop yield obtained from each plot is given in Table 7. The table shows that yield was higher from 23 to $30 \%$ with film hole as compared with conventional irrigation method. The grain yield of the sunflower crop in different experimental plots is given in Fig. 13. With film hole irrigation technique, the yield was more for all the plots as compared with conventional irrigated plots.

\section{Technical/Management Issues Related to Film Hole Technique}

Following technical issues were faced during the film hole Irrigation experiment.

1. Spreading of film hole (Plastic Sheet) on Prepared Seed Bed Spreading of film hole (plastic sheet) on prepared seed bed is an important issue so that all the area of plot should be covered with film hole and no any corner of the plot should be opened and all sides of the film hole should also buried in the soil, so that water can flow freely over the film hole.

2. Making of hole in the film (plastic sheet) Making of hole on film hole at proper location is very important. Plant to plant and row to row distance should be managed carefully, because it is the basic requirement of the crop which is being grown. For making holes a pipe of $5 \mathrm{~cm}$ diameter and $150 \mathrm{~cm}$ length having sharpened edge was used. The sharpened edge was heated on fire and then it was hammered at required spacing marked on the film hole. In this way, holes were made on film hole.

3. Slope of the field (from head to tail) Bordered field slope is also one of the very important factors. At the time of irrigation, if proper slope was not maintained then huge amount of irrigation water will be lost in the field. Therefore, $0.2 \%$ slope was maintained in the field.
Table 7 Sunflower grain yield with film hole and conventional irrigation method

\begin{tabular}{llllll}
\hline Irrigation technique & Treatment & $\begin{array}{l}\text { Discharge } \\
(1 / \mathrm{s})\end{array}$ & $\begin{array}{l}\text { Area } \\
\left(\mathrm{m}^{2}\right)\end{array}$ & $\begin{array}{l}\text { Yield } \\
(\mathrm{kg})\end{array}$ & $\begin{array}{l}\text { Increase in } \\
\text { yield }(\%)\end{array}$ \\
\hline Film hole & 21 & 240 & 59 & 26 \\
Conventional & $\mathrm{FT}_{1}$ & 21 & 240 & 46.8 & \\
Film hole & $\mathrm{CT}_{1}$ & 21 & 144 & 34.56 & 23 \\
Conventional & $\mathrm{FT}_{2}$ & 21 & 144 & 28.08 & \\
Film hole & $\mathrm{CT}_{2}$ & 21 & 120 & 29.8 & 27 \\
Conventional & $\mathrm{FT}_{3}$ & 21 & 120 & 23.4 & \\
Film hole & $\mathrm{CT}_{3}$ & 21 & 72 & 18.28 & 30 \\
Conventional & $\mathrm{FT}_{4}$ & 21 & 72 & 14.04 & \\
\hline
\end{tabular}


Fig. 13 Sunflower grain yield in different experimental plots

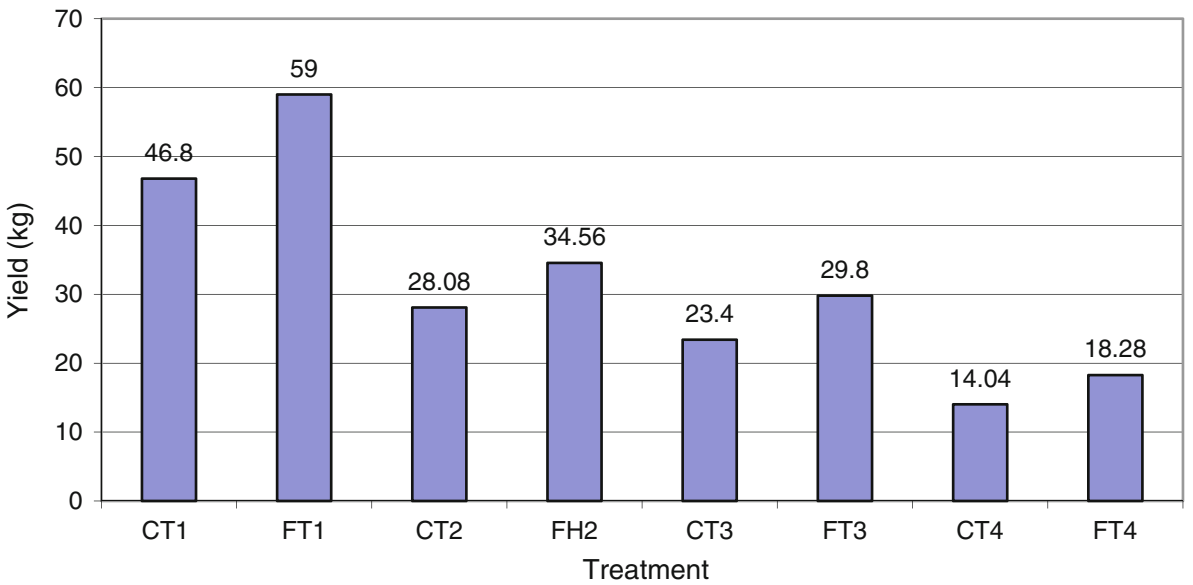

4. Application of pesticides and fertilizers Application of pesticides and fertilizers to the covered plot with film hole is also very important issue. To achieve the good crop yield, it is paramount important to apply pesticides and fertilizers at proper time. So in the film hole treated plots fertilizers and pesticides were applied by mixing it in the bucket and then tap was opened in the plot outlet.

5. Sowing of seeds through holes Labour was required for sowing seeds in the holes. The number of labourers requirement depends on the size of the plots. Machinery could not be used for sowing seeds in film hole treated plots.

6. Growing of weeds under the sheet It was experienced from the experiment that transparent film hole should not be used in the field because it helps weeds to grow under the film hole due to the transmittance of the sun light through the film. Therefore, a black colour film hole should be used in the field to suppress the weeds under the film hole.

\section{Conclusions}

In view of the inherent losses and other inefficiencies of irrigation systems, the film hole irrigation was evaluated with special emphasis on advance rate with conventional irrigation method. The literature in general advocates the beneficial application of film hole irrigation. The present study also proved its usefulness under border irrigation and it can be considered as a good alternative in the future for water saving and increasing crop production. The main findings of the study are summarized as follows:

- In case of film hole irrigation, it was proved as an efficient advance rate technique as it saves $11-22 \%$ of time in terms of the waterfront which accelerate the movement of water over the film. It resulted in better distribution of infiltrated water over the entire length of the border.
- The volume ratio is an appropriate indicator to assess water saving compared to conventional irrigation method as it is observed that with film hole irrigation, water could be saved as $37-45 \%$ as compared with conventional irrigation method.

- Film hole irrigation was applied with $21 \mathrm{l} / \mathrm{s}$ discharge and it was found to be one of the best options for water saving, improving irrigation performance and increasing crop yield.

- It was also observed that height and girth of the sunflower crop were double with film hole irrigation as compared with conventional irrigation method.

- With the help of film hole irrigation, we can suppress the weed growth in the crop as compared with conventional irrigation method.

- Sunflower crop yield was increased from 23 to $30 \%$ with film hole irrigation as compared with conventional irrigation method.

\subsection{Future of Film Hole in Pakistan}

Past research and present field experiment confirmed that the advance of the water front during film hole irrigation can be improved and this is the innovative technique and is an alternative to existing irrigation methods resulting reduction in the volume of applied water as compared with conventional irrigation method. But the results presented in the present study limits its adoptability under conditions, as the length normally used in Pakistan for irrigating the field is only $61 \mathrm{~m}$, compared with longer field lengths mostly used in the developed countries. Further field studies are needed to determine the parameters and dimensions like different soil type and different weather, longer field lengths and different discharge levels and advance rates of film hole and performance parameters before making sound recommendations. Beside all these factors, the most important and controllable 
parameter under field conditions is normally the inflow rate to the bordered field.

Open Access This article is distributed under the terms of the Creative Commons Attribution License which permits any use, distribution, and reproduction in any medium, provided the original author(s) and the source are credited.

\section{References}

1. WAPDA: Drainage Master Plan of Pakistan, vol. II, III. Water Resources Planning Organization. P\&D and IWASRI, WAPDA, Lahore, Pakistan (2005)

2. Mahmood, S.; Latif, M.: Field measurement and simulation of advance ratio for continuous and surge irrigation furrows. Irrig. Drain. ICID 53(4), 37-447 (2004)
3. Ahmad, R.: Irrigation water saving through scientific methods. DRIP Newsletter. Drainage and Reclamation Institute of Pakistan. (12), 4-1 (1991)

4. Jiesheng, H.; et al.: Research state and prospects of mulch technique with plastic membrane. China Rural Water Hydropower (1997)

5. Xiyun, J.; et al.: Developing surface irrigation covered porous plastic membrane, relaxing the crisis of water resource. China Rural Water Hydropower (Supplement), 83-84 (1997)

6. Esfandiari, M.; Maheshwari, B.L.: Application of the optimization method for estimating infiltration characteristics in furrow irrigation and its comparison with other methods. Agric. Water Manag. 34, 169-185 (1997)

7. Goldhamer, D.A.; Aleemi, M.H.; Phene, R.C.: Surge vs continuous flow irrigation. California Agriculture 41(9/10), 29-32 (1987)

8. Belder, P.; Bouman, B.A.M.; Cabangon, R.; Guoan, L.; Quilang, E.J.P.; Yuanhua, L.; Spiertz, J.H.J.; Toung, T.P.: Effect of watersaving irrigation on rice yield and water use in typical lowland conditions in Asia. Agric. Water Manag. 65, 193-210 (2004) 